\title{
The Impact of Cool Roofs on Energy Consumption of Office Buildings in Chongqing of China
}

\author{
Ya-feng Gao*, Kai Zhao, Bin Su, Zhi-qiang Wang and Xiao-min Tang
}

Key Laboratory of the Three Gorges Reservoir Region's Eco-environment Under the State Ministry of Education, Chongqing University, Chongqing 400044, China; National Center for International Research of Low-carbon and Green Buildings, Chongqing University, 400044, China

\begin{abstract}
Cool roofs are characterized by high solar reflectance (SR) and high infrared emittance (E). When cool roofs are exposed to solar radiation, it will have a lower surface temperature compared to a similar surface with lower SR and E values, and this would result in decreasing the heat penetration into the building. Cool roofs offer significant cooling energy saving in buildings with air conditioning. In order to quantify the influence of cool roofs on the energy consumption of office buildings in Chongqing, the authors tested the electricity consumptions of air conditioners in two rooms on the top floor of an office building. One of the rooms was with cooling roof installed. The result shows that in summer, the room with cooling roof saved electricity $0.049 \mathrm{kWh}$ per square meter per day. However in winter, it increased electricity consumption by $0.012 \mathrm{kWh}$ per square meter per day.
\end{abstract}

Keywords: Cool roofs, energy consumption, office buildings.

\section{INTRODUCTION}

In China the energy consumption of the building operation accounts for $26.5 \%$ of the total energy consumption [1]. Of many sources of electrical energy demands within buildings, the electricity used for cooling, heating and ventilation is about $66 \%$ [2].

The cooling load is influenced by the total heat gain within a building. The heat energy entering a building referred as heat gain here, can come from several sources. While heat gain is partly due to occupant body heat, electrical and gas appliances, lighting fixtures and electrical equipment, in hot climate a large portion comes from solar heat gain penetrating through the building's exterior. While the heat gain through windows is the most severe, the energy entering a building through its walls, floors and ceilings is also significant. Most commonly used roofing materials absorb solar radiation and reflect only a small portion of the incident energy. Although the total heat gain for a conventional dark colored roof can be as high as $366 \mathrm{kJm}^{-2}$, the heat loss through the same roof is only about $4.2 \mathrm{kJm}^{-2}[3,4]$, so over the course of the day, heat gain is the predominant process for these roofs.

Any improvement to a building roof that reduces the solar heat gain will result in energy cost savings for the building owner, as well as a reduction in the building's overall environmental impact $[5,6]$. Designers can reduce the roof heat gain in three ways namely by increasing the insulation between the exterior and interior of the building, shading the roof surface from direct sun exposure, and/or by using

*Address correspondence to this author at the Faculty of Urban Construction and Environmental Engineering, Chongqing University, Chongqing 400044,China; Tel: +8618523459600; Fax: (023)65128081;

E-mail: gaoyafeng79@gmail.com reflective roofing materials, also known as 'cool roofs', which reflect and emit radiation more efficiently than conventional roofing materials $[7,8]$.

For a change in the solar reflectivity from 0.2 to 0.85 , the direct energy demand reductions were positive for all the locations. Though in dense high rise building areas, the cool roofs component represents only a low ratio of the total envelope surface, cool roofs have a direct impact on the last floor premises [9].

It must be pointed out that the reduction of absorbed solar radiation could be a penalty for the winter energy demand. Thus, the annual balance of a simple morphology (one story rectangular with terrace roof) has been numerically studied for numerous climates [10].

This paper aims to determine the impact of cool roofs on energy consumption of office buildings in Chongqing, and to study the performances of cool roofs in winter and summer and then an economical analysis will be carried out.

\section{THE MATHEMATICAL MODEL OF COOL ROOFS}

\subsection{Assumed Condition}

In order to simplify the model, and study the cool roofs deeply, it is necessary to make some assumptions and essential premises.

1) Temperature differences between the surfaces of the building are smaller than the near wall temperature difference. Therefore, each surface temperature of building is assumed to be uniform, so horizontal and vertical temperature differences can be used as a lumped parameter to analyze and calculate. Establishing an equation for each surface of the building, not only reduced the calcu- 
lation precision, but also lowered the accuracy and feasibility of this simplification which is reasonable.

2) During the simulation, the weather is sunny, cloudless.

3) During the simulation, the differences of the meteorological parameters are less differentiating, and the temperature of retaining structure surface fluctuates periodically.

4) The indoor temperature of building is constant, showing that the influence is too little to neglect.

\subsection{Mathematical Model}

$\mathrm{q}_{1}+\mathrm{q}_{3}+\mathrm{q}_{5}+\mathrm{q}_{4}-\mathrm{q}_{2}-\mathrm{HG}(N)=0$

Where

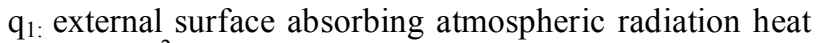
transfer, $\mathrm{W} \cdot \mathrm{m}^{-2}$;

$\mathrm{q}_{2}$ : external surface radiation heat transfer, $\mathrm{W} \cdot \mathrm{m}^{-2}$;

$\mathrm{q}_{3}$ : external surface absorbing radiation heat transfer from objects around, $\mathrm{W} \cdot \mathrm{m}^{-2}$;

$\mathrm{q}_{4}$ : convective heat transfer from outdoor air to external surface, $\mathrm{W} \cdot \mathrm{m}^{-2}$;

$\mathrm{q}_{5}$ : external surface absorbing solar radiation heat transfer, $\mathrm{W} \cdot \mathrm{m}^{-2}$; $\mathrm{W} \cdot \mathrm{m}^{-2}$;

HG $(\mathrm{N})$ : heat transfer by retaining structure in $\mathrm{n}$ time,

The calculation method of each parameter can be found in reference [11].

\section{ANALYSIS OF A CHINA CASE STUDY}

The main objective of this study is to demonstrate that the cool roofs techniques are able to bring energy, thermal comfort and environmental benefits to the Chinese building stock. This case study is intended as an example of the cool roofs role in improving the indoor thermal conditions and in reducing the energy consumption in cooled buildings. Overheating in the summer has been repeatedly reported by the occupants, mainly due to failures of the air conditioning system: cool roofs application is revealed to be a solution to mitigate indoor summer discomfort conditions.

\subsection{Description of the Building}

The building considered in this case study is a five-storey office building located in Shapingba District, Chongqing, China (latitude 29 $34^{\prime} 12^{\prime \prime}$, and longitude 106 $27^{\prime} 36^{\prime \prime}$ ), which is representative of building constructions characterised by a high cooling energy demand. The two main facades are north and south oriented. The thermal resistance of flat roof is $0.67 \mathrm{~m} 2 \mathrm{~K} / \mathrm{W}$. For Room B, the roof coating was refurbished at the end of May 2012, with a solar reflectance of 0.82 and a thermal emittance of 0.88 .

The geometrical characteristics (areas and the volumes) of the top floor of the building are presented in Fig. (1):

\subsection{Envelope Characteristics}

The framework of the building is built of reinforced concrete and the masonry consists of volcanic limestone uninsulated blocks. The external surface finishing is of gray plaster.
The windows consist of single glass with aluminum frame. The facades are provided with external vertical concrete elements as solar obstructions which are particularly effective for north and south exposures. The roof external finishing is of gray concrete tiles.

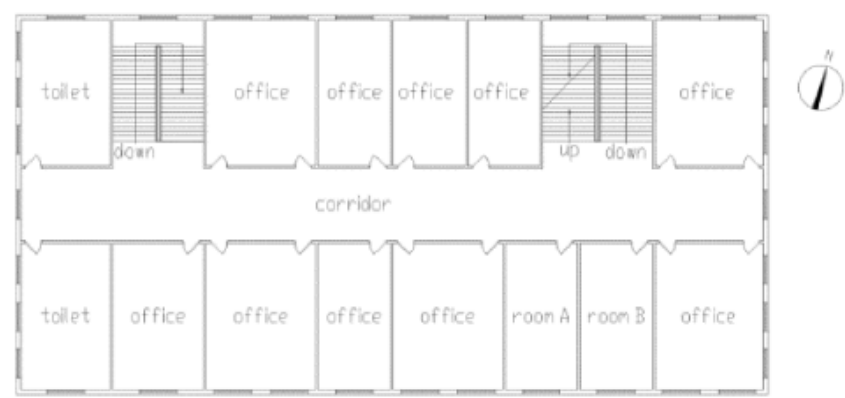

Room A-Default roof

Room B-Cool painted roof

Fig. (1). Plan of the top floor of the testing office building.

There is an installed electric heat pump system for both heating and cooling conditioning with split type air conditioner in each zone (Table 1).

Table 1. Indoor air-conditioning parameters.

\begin{tabular}{|c|c|c|}
\hline Rooms & A & B \\
\hline \hline Cooling capacity & $5000 \mathrm{~W}$ & $5090 \mathrm{~W}$ \\
\hline Cooling power & $1860 \mathrm{~W}$ & $1490 \mathrm{~W}$ \\
\hline EER & 2.68 & 3.42 \\
\hline Heating capacity & $5600 \mathrm{~W}$ & $5750 \mathrm{~W}$ \\
\hline Heating power & $1780 \mathrm{~W}$ & $1620 \mathrm{~W}$ \\
\hline COP & 3.14 & 3.55 \\
\hline
\end{tabular}

\subsection{Locations of Measuring Points}

The measuring points of roofs surface temperatures are gauged with an infrared thermometer. Air temperatures are measured with self-recording thermo-hygrometer protected from irradiations (tube with high solar reflectivity and low thermal emittance, vertical for natural ventilation) and laid according to the following distribution.

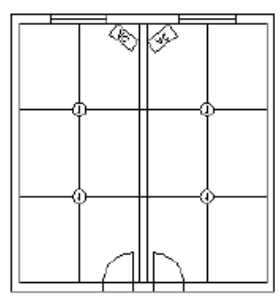

(a)

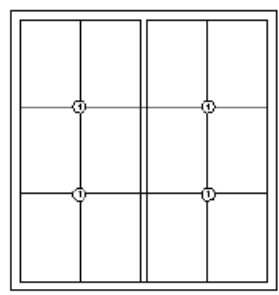

(b) a. The indoor ceiling temperature measuring points. b. The external surface temperature measuring points.

Fig. (2). Locations of Measuring Points in Rooms A and B. 
Table 2. Performance parameters of experimental instruments.

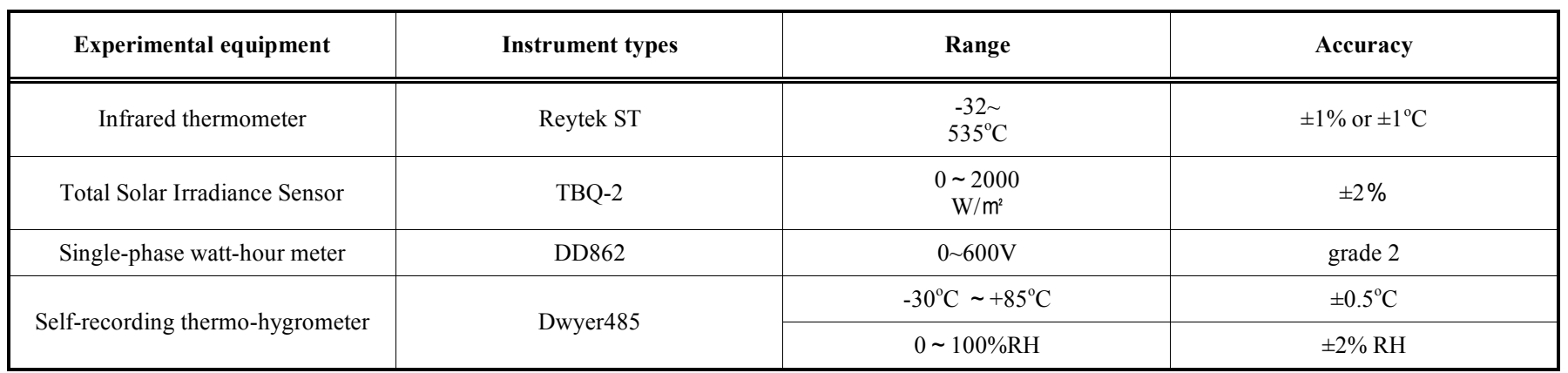

\section{EXPERIMENTAL RESULTS AND DISCUSSION}

In the first part, we will focus on the temperature variations due to the use of cool paints, and in the second part, the energy efficiency of the cool paints is analyzed.

\subsection{Analysis of Cool Roofs Simulated External Surface Temperature}

Based on the cool roofs external surface heat balance equation, a numerical model was established to analyze the cool roofs external surface temperature variation trend. The simulation time was 12th August. The simulated temperatures are compared with the measurement temperatures (Fig. 3). The two temperature lines vary with a similar tendency. The measured and simulated temperatures deviation is about $1-6 \%$, and the average deviation is about $3 \%$. The simulation results are accurate and reliable.

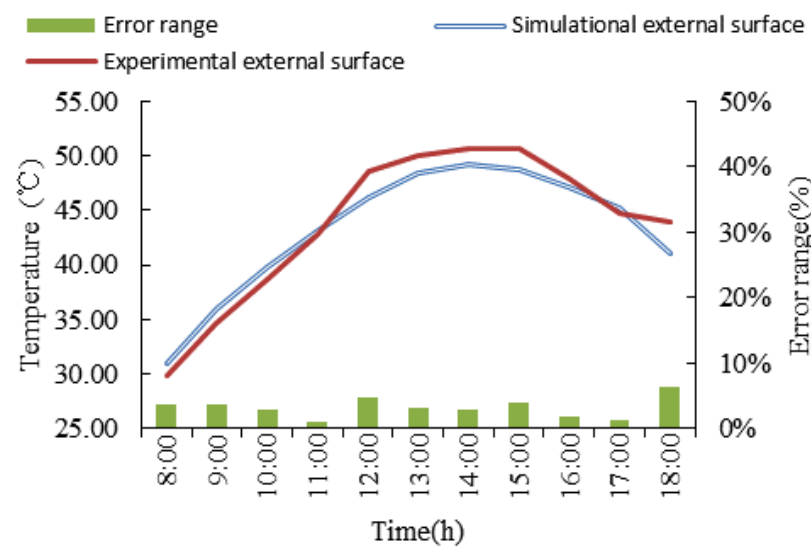

Fig. (3). Simulation and experiment external temperatures of cool roofs on 12th August.

Originally, the solar reflectance of cool roofs is 0.82 . Considering the impact of the dust, the solar reflectance will be reached and stabilized at 0.5 . Changing the solar reflectance of cool roofs, the external surface temperature of cool roofs is shown in Fig. (4) (solar reflectance ranging between $0.5-0.82)$ :

Under the same conditions, the peak external surface temperature increased with the solar reflectance increase. When the solar reflectance dropped from 0.82 to 0.5 , the peak external surface temperature increased from $49.22^{\circ} \mathrm{C}$ to $58.80^{\circ} \mathrm{C}$. To maintain the energy-efficient cool roofs, Regular cleanings is extremely important.

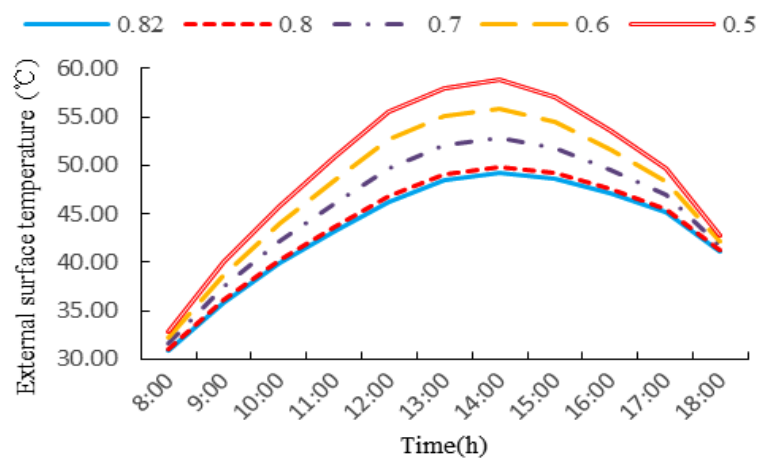

Fig. (4). The external surface temperature of cool roofs with different solar reflectance.

\subsection{Temperature Evolutions}

The temperature data measured on the default roof rooms A and the cool painted roof rooms B were averaged to show the temperature differences for both the indoor ceiling and outdoor roof surfaces. Fig. (5) shows the internal and external surface temperatures for both roof A and roof B for five days from January 24th to 28th and seven days from August 11 th to 15 th, 2012. Although the temperatures for both the internal and external surfaces fluctuate over the datacapturing period, the temperature differences between the default and the cool painted roof surfaces were fairly consistent. With the external surface temperature difference being about $9-14^{\circ} \mathrm{C}$, the indoor ceiling temperature is about 2.5 $4.1^{\circ} \mathrm{C}$ in January, and with the external surface temperature difference being about $16.7-22.1^{\circ} \mathrm{C}$ and the indoor ceiling temperature is about $3.9-9.4^{\circ} \mathrm{C}$ in August.

As shown in Fig. (4), in January, the average indoor ceiling temperature of rooms $\mathrm{A}$ and $\mathrm{B}$ was changing between $11.9^{\circ} \mathrm{C} \sim 16.4^{\circ} \mathrm{C}$ and $11.3^{\circ} \mathrm{C} \sim 13.7^{\circ} \mathrm{C}$ respectively. The average temperature fluctuation of rooms $\mathrm{A}$ and $\mathrm{B}$ is about $4.5^{\circ} \mathrm{C}$ and $2.4^{\circ} \mathrm{C}$ respectively. In August, the average indoor ceiling temperature of roof A was changing between $32.9^{\circ} \mathrm{C} \sim$ $46^{\circ} \mathrm{C}$ and the average fluctuation is about $13.1^{\circ} \mathrm{C}$. The average indoor ceiling temperature of roof $\mathrm{B}$ varied between $31.4^{\circ} \mathrm{C} \sim 40.5^{\circ} \mathrm{C}$ and just has a $9.1^{\circ} \mathrm{C}$ average fluctuation.

The cool roof can reduce the external surface temperature of room effectively and uniformly, and extend the working life of waterproof materials, so that it ensures the waterproofing reliability. It offers positive significance for rainy weather conditions of Chongqing. 

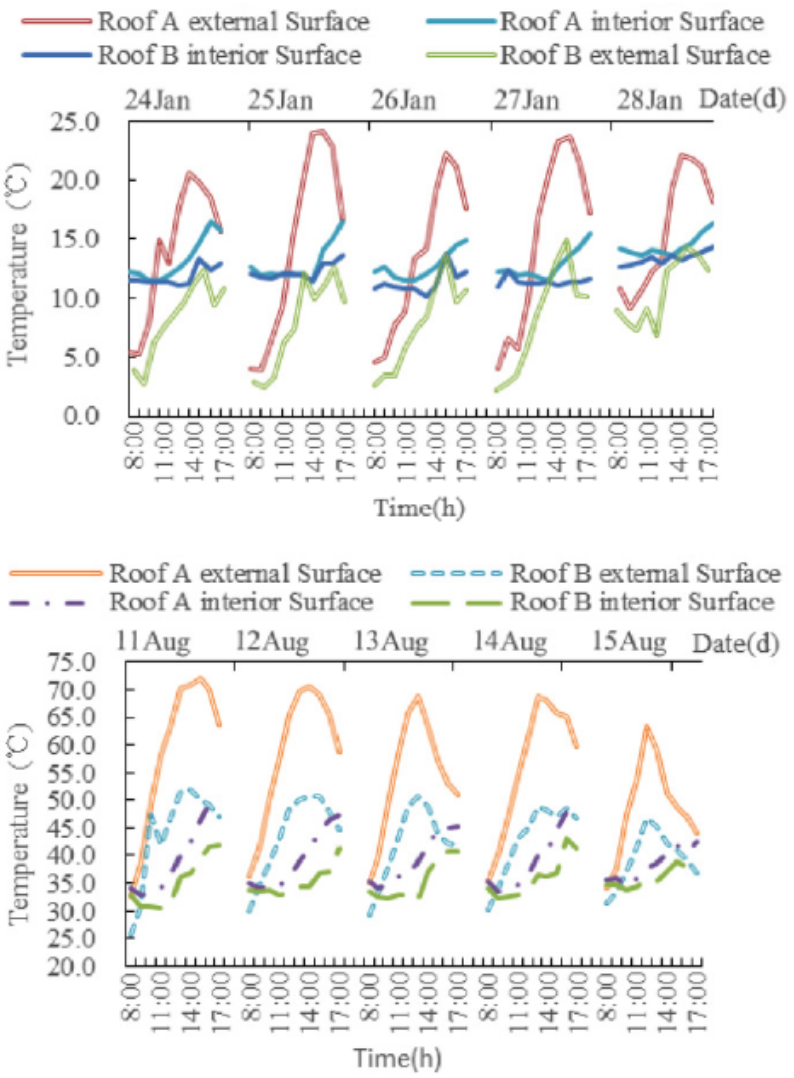

Fig. (5). Temperatures Difference Between Roof A (Default Roof) and Roof B (Cool Painted Roof): Between Jan (24-28) and Aug (11-15).

The external surface temperature and the indoor ceiling temperature increase during 10:00 and 14:00, since from 10:00 the solar radiation intensity begins to increase gradually. Therefore, the room becomes hot. Until 14:00 the temperature reaches the highest value and the heat exchange between indoor and outdoor increases. So, there are two times low-amplitude increments.

\subsection{Energy Saving Measurements Results}

Fig. (6) shows the daily electricity consumption for the two different scenarios. With cool roofs coverage, daily total electricity reduction ranges from $9.30 \%$ to $12.40 \%$ from August 11 th to 15 th and increase ranges from $8.13 \%-$ $12.26 \%$ from January 24 th to 28 th.

By the calculation, the average energy consumption of default roof room and cool painted roof room are $3.14 \mathrm{kWh}$ and $3.47 \mathrm{kWh}$ for January 24 th to $28 \mathrm{th}$. The cool roof room has an area of 28 square meters, so the average energy consumption increase of cool roofs is $0.012 \mathrm{kWh} /\left(\mathrm{m}^{2} \bullet \mathrm{d}\right)$. The average energy consumption of default roof room and cool painted roof room is $11.72 \mathrm{kWh}$ and $10.36 \mathrm{kWh}$ respectively from August 11 th to 15 th. The average energy consumption reduction of cool roofs is $0.049 \mathrm{kWh} /\left(\mathrm{m}^{2} \bullet \mathrm{d}\right)$

Testing results show that the cool roofs can reduce the office building energy consumption in summer and increase the energy consumption during winter. Obviously, the average energy consumption reduction in summer is greater than the average energy consumption increase in winter. Mean- while the average cooling degree days (CDD) is $1171.2^{\circ} \mathrm{C} \cdot \mathrm{d}$ and the average heating degree days (HDD) is $1138.8^{\circ} \mathrm{C} \cdot \mathrm{d}$ in Chongqing [12], which are basically the same. Therefore, the annual balance of energy consumption will benefit the energy saving of office buildings in Chongqing, China.
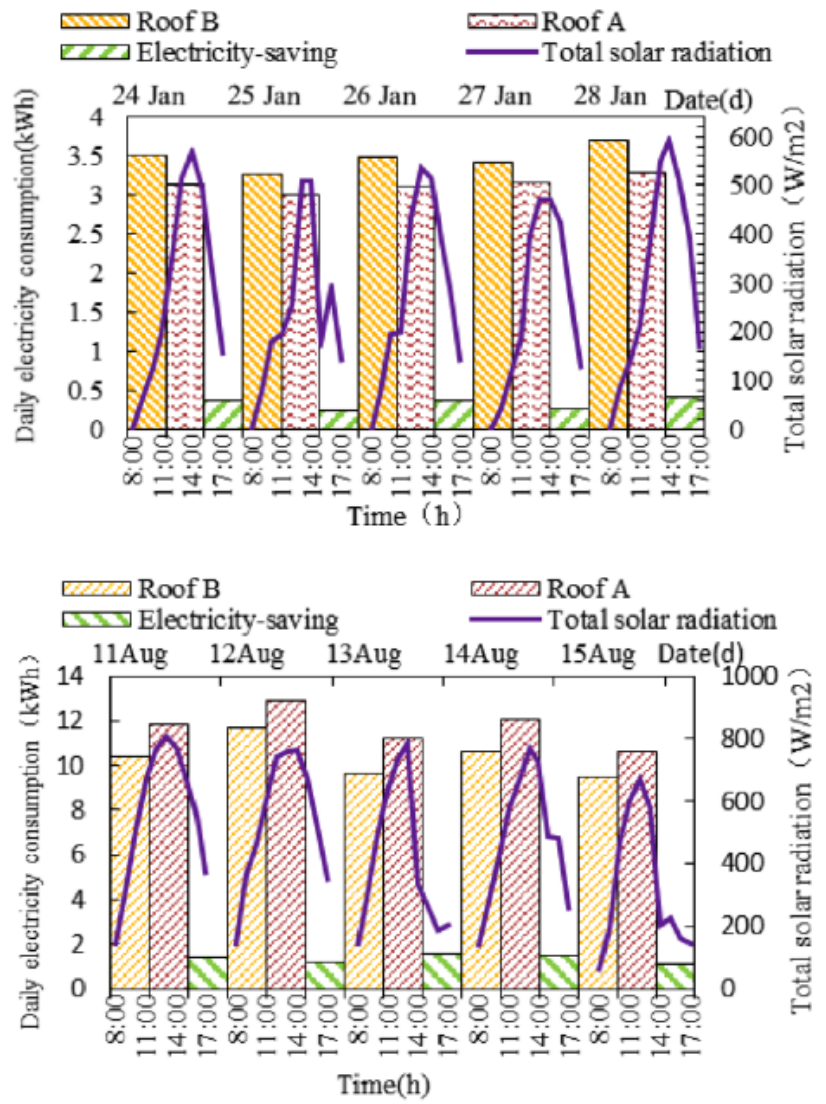

Fig. (6). Daily Electricity Consumption Difference Between Roof A (Default Roof) and Roof B (Cool Painted Roof): Between Jan (24-28) and Aug (11-15).

Table 3 presents the results of the room electricity usage for default roof and cool painted roof. The measuring results show that for roof $\mathrm{B}$, the average daily increase in the electricity consumption is $0.33 \mathrm{kWh}(1.19 \mathrm{MJ})$ in January, while in August, the average daily reduction in the electricity consumption is $1.47 \mathrm{kWh}(5.29 \mathrm{MJ})$. The commercial electricity price of Chongqing is 0.843 (Yuan $/ \mathrm{kWh}$ ), if below $1.0 \mathrm{kV}$.

Table 3. Energy saving from cool roofs construction.

\begin{tabular}{|c|c|c|}
\hline & Jan 24th to 28th & Aug 11th to 15th \\
\hline \hline $\begin{array}{c}\text { Average energy saving } \\
(\mathrm{kWh} / \mathrm{d})\end{array}$ & 0.33 & 1.47 \\
\hline $\begin{array}{c}\text { Daily electricity savings } \\
(\mathbf{¥} 0.843 \text { per } \mathrm{kWh})\end{array}$ & $\mathbf{\$} 0.28$ & $\mathbf{\mathbf { N }} 1.24$ \\
\hline $\mathrm{kWh} /\left(\mathrm{m}^{2} \bullet \mathrm{d}\right)$ & 0.012 & 0.049 \\
\hline
\end{tabular}

The monthly peak-time electrical power demand of the building is an important factor to consider, as commercial 
and public facilities are often charged peak power fees based on these values. Utilities charge more for high peak power because it increases the amount of total power capacity needed even if the peak only lasts for a few minutes. Providing more capacity may require the utility to run additional power plants that may only be used intermittently during extreme power demand periods, as well as extra transmission lines and distribution centers. Any decrease or shift in peak power demand is, therefore, considered to be beneficial by both the utility company and the building owner.

\section{CONCLUSION}

The benefits of using cool roofs systems are well known in the industry. However, there have been few practical cases using full-scale operational buildings. This study, therefore, implemented a research methodology that uses actual field data to quantify the annual electricity savings of an operational office building.

1) Based on the cool roofs external surface prediction model, the measured and simulated temperatures average deviation is about $3 \%$. It means that the simulated temperatures are dependable.

2) In comparison with default roof, cool roof has lower external surface temperature difference. It can auto extend waterproof materials life, ensuring waterproofing reliability. It offers positive significance for rainy weather conditions of Chongqing.

3) For the cool roofs, the average energy consumption reduction in summer is greater than the average energy consumption increase in winter. Meanwhile the average cooling degree days (CDD) is basically the same with the average heating degree days (HDD). Therefore, the annual balance of energy consumption will benefit the energy saving of office buildings in Chongqing, China.

\section{CONFLICT OF INTEREST}

The authors confirm that this article content has no conflict of interest.

\section{ACKNOWLEDGEMENTS}

This work is supported by Chongqing city fundamental and advanced research projects (No.CSTC2014jcyjA90018), the National Natural Science Foundation of China, under Grant (No.51178481), Fundamental Research Funds for the Central Universities of China under Grant (No. CDJZR12210013 and No. 106112014CDJZR210006), and The 111 Project of China under Grant No.B13041.

\section{REFERENCES}

[1] China's energy development strategy and policy research group, China's energy development strategy and policy research, Economic and Scientific Press House, Beijing, 2004.

[2] Y. Jiang, "Current building energy consumption in China and effective energy efficiency measures," $H V \& A C$, vol. 35 , no. 5, pp. 30-40, 2005.

[3] A. Synnefa, M. Santamouris, and I. Livada, "A study of the thermal performance of reflective coatings for the urban environment," Solar Energy, vol. 80, no. 8, pp. 968-981, 2006.

[4] A Synnefa, A. Dandou, M. Santamouris, and M. Tombrou. "On the use of cool materials as a heat island mitigation strategy," Journal of Applied Meteorology and Climatology, vol. 47, no. 11, pp. 28462856, 2008.

[5] R. Levinson, A. Hashem, and B. Paul, "Measuring solar reflectance-Part II: Review of practical methods," Solar Energy, vol. 84, no. 9 , pp. 1745-1759, 2010.

[6] A. Synnefa, and M. Santamouris, "Advances on technical, policy and market aspects of cool roof technology in Europe: The Cool Roofs project," Energy and Buildings, vol.55, pp. 35-41, 2012.

[7] J. H. Jo, J.D. Carlsonb, J.S. Goldena, and H. Bryan, "An integrated empirical and modeling methodology for analyzing solar reflective roof technologies on commercial buildings," Building and Environment, vol. 45, no. 2, pp. 453-460, 2010.

[8] H. Akbari, and K. Steven, "Calculating energy-saving potentials of heat-island reduction strategies," Energy Policy, vol. 33, no. 6, pp. 721-756, 2005.

[9] M. Doya, E. Bozonnet, and F. Allard, "Experimental measurement of cool facades' performance in a dense urban environment," Energy and Buildings, vol. 55, pp. 42-50, 2012.

[10] A. Synnefa, M. Santamouris, and H. Akbari, "Estimating the effect of using cool coatings on energy loads and thermal comfort in residential buildings in various climatic conditions," Energy and Buildings, vol. 39, no. 11, pp. 1167-1174, 2007.

[11] Y. Qi-sen, and Z. Qing-zhu, "Building thermal process," China Architecture \& Building Press, Beijing, 1986.

[12] T.Y. Ruifen, and H. Z. Yu, "Verification of the tropical cyclone positioning and forecasts over the western north pacific in 2008," Atmospheric Science Research and Application, vol. 2, 2009.

\begin{tabular}{lc}
\hline Received: April 10, 2015 & Revised: May 20,2015 \\
C) Gao et al.; Licensee Bentham Open. &
\end{tabular}

(C) Gao et al.; Licensee Bentham Open.

This is an open access article licensed under the terms of the (https://creativecommons.org/licenses/by/4.0/legalcode), which permits unrestricted, noncommercial use, distribution and reproduction in any medium, provided the work is properly cited. 